\title{
THE EFFECT OF SOCIAL COMMERCE CONSTRUCT AND BRAND IMAGE ON CONSUMER TRUST AND PURCHASE INTENTION
}

\author{
Zakky Zamrudi, Imam Suyadi, Yusri Abdillah \\ Faculty of Administrative Science, University of Brawijaya Malang \\ Email: jzakky@gmail.com
}

\begin{abstract}
Social commerce is a new development of e-commerce by using social media platform to interact on the internet. Current studies only examine the model on its own basis by using direct effect only. This research examines both of the model together to reveal which factor that give the greater effects against consumer trust and purchasing intention both direct effect, indirect effects and total effects. Drawing a literature from marketing and information systems (IS) the author proposes a model to understand the relationship between social commerce construct and the brand image against the purchasing intention in Instagram. The study utilized Generalized Structured Component Analysis (GSCA) methodology to test the model. The research object was the @ fujifilm_id instagram followers as many as 99 respondents. Results shows that social commerce construct are likely to give greater effect against the purchase intention rather than by the brand image whether in direct, indirect and total effect. Yet, the brand image is a crucial part of a brand which is needed to be maintained against customer perspective. Implication, limitation, discussion and future research direction are also discussed.
\end{abstract}

Keywords: social media, instagram, social commerce, GSCA

\begin{abstract}
ABSTRAK
Social commerce merupakan pengembangan baru dari e-commerce dengan menggunakan media sosial untuk berinteraksi di internet. Studi yang ada saat ini hanya menguji model secara terpisah secara langsung. Berdasarkan ide ini, penelitian ini mencoba untuk menguji kedua model secara bersamasama untuk mengungkapkan faktor manakah yang memberikan efek yang lebih besar terhadap kepercayaan konsumen dan niat pembelian baik secara langsung, maupun tidak langsung serta efek secara total. Mengambil literatur dari ilmu pemasaran dan sistem informasi (IS) penelitian ini mengusulkan sebuah model untuk memahami hubungan antara konstruk social commerce dan citra merek terhadap niat beli melalui media sosial Instagram. Metodologi yang digunakan untuk menguji model adalah Generalized Structured Component Analysis (GSCA). Objek penelitian ini adalah pengikut instagram @fujifilm_id sebanyak 99 responden. Hasil menunjukkan bahwa konstruks social commerce cenderung memberikan efek yang lebih besar terhadap niat beli daripada oleh citra merek baik secarak langsung, tidak langsung dan total. Namun, citra merek adalah bagian penting dari merek yang perlu mempertahankan terhadap perspektif pelanggan. Implikasi, batasan, diskusi dan arah penelitian dijelaskani pada bagian akhir
\end{abstract}

Kata Kunci: media sosial, instagram, social commerce, GSCA 


\section{INTRODUCTION}

Social media interaction grows rapidly as a viral communication alternative in the contemporary society. This allows people to create virtual communication through social networking sites (SNS). In terms of SNS's, the largest social media today are remaining the behemoth ubiquitous Facebook, following by Instagram and the last is twitter (statista.com, 2015).

The involved social media in this research is Instagram. Instagram users may just a fraction of the Facebook precedents, but the interaction rates of social marketing are higher than Facebook. Brooks (2014) stated that Instagram community of 150 million monthly active users is a fraction of the size of Facebook's, yet the interaction rates for posts made by the 249 brands studied were 15 times higher on Instagram than on Facebook.

Contemporarily, social media commerce (s-commerce) emerges as a tool for company's marketing strategy to promote its products and updated information. The use of social media interaction for commercial purpose is then known as social commerce. The term "social commerce" was first introduced in 2005 by Yahoo! (Rubel 2005).

In terms of the ad spending, Asia pacific was the second largest country on social network ad spending (emarketer.com, 2014). Indonesia was the third-largest market population in the area of Asia-Pacific. Total media spending were nearly $\$ 11.16$ billion by 2014 which is doubled than that in the India region. But in terms of digital ad spending, Indonesia was taken a smaller area of this comparison as shown on table 1. Empowering the social media will take a deep understanding for successful implementation of social commerce strategies. The rapid growth of technology development has led the social networking media growing faster. It is necessary to pay more attention on spending the promotional funds, especially spending on social media analysis and implementation.
In analyzing the demanding research in the area of electronic commerce, the new paradigm was introduced as the "Social Commerce Construct (SCC's). According to Hajli (2015) Social commerce is a new stream and a subsets of e-commerce which enables consumers to take action in generating content. Kim and Park (2013) explain S-commerce as a form of online business that combining an eCommerce with social media such as Social Networking Sites (eg: facebook) to provide the consumers with daily deals from local establishments. Hardagon and Becky (2006) stated that a social commerce will enables vendors to reach different markets by integrating social interactions of consumers.

Table 1 ad spending in indonesia

Total Media, Digital and Mobile Internet Ad Spending in Indonesia, 2013-2018 (In Billions)

\begin{tabular}{lrrrrrr}
\hline & 201 & 201 & 201 & 101 & 201 & 201 \\
& 3 & 4 & 5 & 6 & 7 & 8 \\
\hline Total & $\mathbf{\$ 9 . 1}$ & $\mathbf{\$ 1 1 .}$ & $\mathbf{\$ 1 2}$. & $\mathbf{\$ 1 5 .}$ & $\mathbf{\$ 1 7 .}$ & $\mathbf{\$ 1 9 .}$ \\
media & $\mathbf{4}$ & $\mathbf{1 6}$ & $\mathbf{9 4}$ & $\mathbf{0 1}$ & $\mathbf{2 6}$ & $\mathbf{5 1}$ \\
ad & & & & & & \\
spend & & & & & & \\
ing & & & & & & \\
Chang & 20.0 & 22.0 & 16.0 & 16.0 & 15.0 & 13.0 \\
$e$ & $\%$ & $\%$ & $\%$ & $\%$ & $\%$ & $\%$ \\
Digita & $\mathbf{\$ 0 . 2}$ & $\mathbf{\$ 0 . 5}$ & $\mathbf{\$ 0 . 9}$ & $\mathbf{\$ 1 . 6}$ & $\mathbf{\$ 2 . 6}$ & $\mathbf{\$ 3 . 9}$ \\
l ad & $\mathbf{7}$ & $\mathbf{3}$ & $\mathbf{5}$ & $\mathbf{1}$ & $\mathbf{6}$ & $\mathbf{9}$ \\
spend & & & & & & \\
ing & & & & & & \\
Chang & 90.0 & 98.0 & 80.0 & 70.0 & 65.0 & 50.0 \\
$e$ & $\%$ & $\%$ & $\%$ & $\%$ & $\%$ & $\%$ \\
Mobil & $\mathbf{\$ 0 . 0}$ & $\mathbf{\$ 0 . 0}$ & $\mathbf{\$ 0 . 0}$ & $\mathbf{\$ 0 . 1}$ & $\mathbf{\$ 0 . 2}$ & $\mathbf{\$ 0 . 5}$ \\
e & $\mathbf{1}$ & $\mathbf{2}$ & $\mathbf{5}$ & $\mathbf{2}$ & $\mathbf{7}$ & $\mathbf{5}$ \\
intern & & & & & & \\
et ad & & & & & & \\
spend & & & & & & \\
ing & & & & & & \\
\hline chang & 110 & 130 & 130 & 130 & 130 & 100 \\
$e$ & $\%$ & $\%$ & $\%$ & $\%$ & $\%$ & $\%$ \\
\hline
\end{tabular}

The research taken in this study will analyze about the current phenomena of digital camera industry development which is growing rapidly today. The digital camera market trends has been moving from regular DSLR (digital single lens reflex) to mirror-less camera. People are more mobile today and for some reason they tend to choose the mobile devices and a bunch of accessories. This research is take at the brand of Fujifilm since this brand is growing today. This company has showing a good market 
development only in a year's showing by rapid growth from sixth month to 12 month of 2014 (Zang, 2015).

\section{THEORETICAL BACKGROUND AND HYPOTESIS}

\subsection{E-commerce}

Business activity has been evolve rapidly in recent years by the advancement of human necessity. In this todays digital era, company must adapt its business to fit with the consumer environment by using eCommerce. Electronic commerce (eCommerce) has been a part of the electronic business operation. Conceptually, eCommerce is aimed to taking a part of business operation obviously dealing with customer. e-commerce as the activity of purchase or selling product through websites services. It is means that both seller and buyer are able to communicate virtually through the networking platform via websites user interface (Kalakota and Robinson, 2001; Laudon and Laudon, 2012).

\subsection{S-commerce}

The term "social commerce" was first introduced in 2005 by Yahoo! (Rubel 2005). It was been launched on November 11, 2005, Yahoo!'s Shoposphere is the earliest attempt to plunge into social commerce (Rothberg 2005). Social commerce is any way for user to generate any content such as text, image, sound, or moving image (video) and etc., Social commerce is a new stream and subsets of e-commerce which enables consumers to generate content by using web application or specialized application (Hajli ,2014; Lian and Turban, 2011). For the vendors social commerce can be used as a powerful tools to interact with its customer. Social commerce enables vendors to reach different markets by integrating social interactions of consumers (Hargadon and Bechky, 2006).

Characteristics for social commerce that consist of seven characteristics consist of reputation, size, information quality, transaction safety, communication, economic feasibility and WOM referrals (Kim and Park, 2013).

\subsection{Social Commerce Construct}

The experience of consumers in an online environment enabled by social media is different to that offline, as the customers have social interactions with other individuals (DoHyung, Jumin, and Ingoo, 2007). In the part of social commerce, it is understood that social commerce is a new way to engage with the company by using social media platform. These social platforms are known as social commerce constructs, which this research will investigate (hajli, 2015). The use of social commerce construct is initiated by several research in the area of social commerce. One of them are the research taken by Kim and Park (2013) that mentioned several characteristics of social commerce consist of reputation, size, information quality, transaction safety, communication, economic feasibility, and word-of-mouth referrals.

Hajli and Sims (2015) define social commerce as a new stream in e-commerce, where social factors are the determinant of this phenomenon and consumers are empowered to generate content using social media through online communities, forums, ratings, reviews and recommendations. Some other researcher also mention ratings and review as the construct of SCC's (Chen, Xu, \&Whinston, 2011), recommendation and referrals form friends (Senecal and Nantel, 2004), and forum and communities (Bagozzi and Dholakia, 2002). Hajli (2015) explained the Social commerce construct (SCC's) by using three dimension. The dimensions are consist of ratings and review, recommendation and referrals, forum and communities.

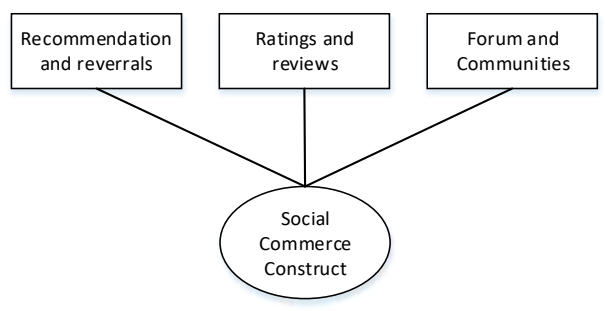

Figure 1 social commerce construct 


\subsection{Brand image}

Brand image has been an important part to strengthen the brands name in the customer mind. According to Keller (1993) brand image and brand awareness are the two dimension of brand knowledge. Kotler et al., (1999) has briefly defined brand image as the set of beliefs held about a particular brand is known as the brand image. Ferrell and Hartline (2011) define brand image as the overall impression, positive or negative, that consumer have in mind. This impression was includes what the organization has been done in the past, what is the current offering to its customer, and the projections about what will it do in the future. All aspects of the firm's marketing program, as perceived by customers, also will effects the impression the customer.

Brand image have several purpose in order to create a clear and appropriate message to consumers. Hubanic and Hubanic (2008) explained the four purposes of brand images such as Brand image communicates expectations, Brand image influences the perception of a company's activities, Brand image is a result of consumers' experiences and expectations.

In determining the dimension of brand image in the daily practice, there will five dimension in understanding the brand image such as (a) brand identity, (b) brand personality, (c) brand association, (d) brand attitude and behavior, and (e) brand benefit and competence (Wijaya, 2013).

\subsection{Trust}

Trust is always becoming a crucial issues in most economics and social transaction particularly on the online context where there may contain a lot of uncertainty. Mutz (2005) stated that Trust will become the important aspect when risks are perceived to be higher as what is often happened on e-commerce particularly on s-commerce. By the increase of social technologies and interconnectivity of people on the Internet, there is a need for some sort of trust and security that will allow two parties to reduce their perceived risk in transactions (Hajli \& Lin, 2014).

The research by Gefen and Straub (2004) shows that people are likely reducing their social uncertainty in the era of internet advancement. It is also argued that if an ecommerce website describes products or services accurately, consumers will trust the website more (Hsien et al., 2009). This can be facilitated by social technologies such as customer reviews, information and experiences of others in forums and communities. Rotter (1971) was defined the interpersonal trust as an expectancy held by any individual or any group that the word, promise, verbal or written statement of another individual or group can be relied on. To gain consumer trusts against brand, it can be achieved when the consumer expectation against any particular product has been fulfilled. Trusts will emerge when consumer feel satisfied with the product or services received. By emerging the trust on the current consumer company will able to draw a larger trusts from societies. The sustainability also becoming the crucial topics for company in satisfying the customer.

Ferinadewi (2008) categorize three main activities to build customer trust by the company such as achieving the results which means that consumers expectation are the promises to consumers that the company must be fulfilled, Acting with integrity which means that there must have a consistent action from what has been promised (described) in any situation, Demonstrated concern which means the company ability to give an attention to consumers by understanding the consumers difficulties in consuming products, and Level of trusts which means the last measurement of the three steps done by the company. It also can be used as the measurement level for plan succession. Robbins and Jugde (2007) mentions four key dimensions of the concept of trust, namely integrity, competencies, consistency, and transparency. 


\subsection{Purchase Intention}

Purchase intention is gathered from any learning process and thinking process that emerging any perceived feeling against particular product. According to Keller (1993), consumer interest is how consumers most likely to buy a brand or how large consumers the possibility to switch from one brand to another brand. According to Kotler (2005) purchase intention is placed in the phase of evaluation of alternatives in buyer decision process. In the phase between evaluation of alternatives and purchase decision consumers will form with a purchase intention to make purchases (Kotler, 2005). Consumer will compare or consider the goods by goods more for their consumption. There are at least two factor that will establish consumer purchase intention. Kotler (2005) defining the factors that will establish consumer purchase intention consist of the attitude of others and factors unanticipated situation. According to Ferdinand (2006), purchase intention can be identified through the following indicators such as transactional interest, referential interest, preferential interest, and exploratory interest.

\section{Conceptual Framework And Hypotheses}

\subsection{Social commerce construct against Purchase Intention}

From the previous explanation, it can be made any explanation of each relationship among variable. Hajli (2015) defined Social Commerce Construct as social platforms which have emerged and empowered consumers to generate content and share their experiences in an open communication platform. It's also enable consumer to use others' information, offer advice and share their experiences. It means that when consumer are going to engage, company are able to create such environment in the area of consumers to give any referrals and reviews against other. The research finding by Hajli (2015) has shown that there are a significant relationship between social commerce construct and purchase intention from current consumer engagement.

The finding by Hajli (2015) also supported from previous research that individually researched each dimension of SCC's effect on purchase intention. Yubo and Jinhong (2005) find that the third party review are significantly effects consumer purchase decision. Senecal and Natel (2004) find that online recommendations strongly influence the online choice of product. Ridings and Gefen (2004) also find that anticipation of people in any online communities, with information exchange, is the main reason for joining virtual communities. This has a direct influence on customer behavior.

H1: Social Commerce Construct (SCC's) are effects purchase intention

\subsection{Social commerce construct against Trust}

Social commerce construct is also effects the consumer trust. In this section consumers trusts are started to be involved. Since the users of social media users are mostly have never been met before. The reliability and trustworthiness amongst users are being a huge questions mark for the users. Hajli (2015) find that the social commerce construct has a significant effect on consumer trust. The finding was also being supported by Kim and Park (2013) research finding on analyzing the social commerce construct relationship with consumer trust, which is means that the members of forum roles in terms of referrals and recommendation, ratings and reviews, forums and communities.

H2: Social Commerce Construct (SCC's) is effects trust

\subsection{Brand Image against Purchase Intention}

Brand image defined as set of beliefs held about a particular brand on customer mind (Kotler et al., 2005). It means that a brand threated as a human being that has its attitude. Those attitudes are become the benchmark of 
how people will appraise those attitude through several action such as purchase intention. Agekyan (2009) was find that the brand image has a significant effect only for two products. Arista (2011) find that the brand image have a high significant effect against purchase intention. Prabowo (2014) finding also consistent with previous research that brand image are significantly effects the purchase intention.

H3: Brand Image effects purchase intention

\subsection{Brand Image against Trust}

Trust has also has a relationship with brand image. The better the brand image the higher the consumer will trust the brand (Prabowo, 2011; Arista, 2011). This is means that the consumer trust is also effected by the consumer's perspective against the brand which is defined by the brand image of any particular trademark. Lau and Lee (2000) states that the characteristics of brand building brand image is relatively more important in its effect on consumer confidence in the brand. Finding by Semuel and Lianto (2014) shows that there is a significant effect from brand image and purchase intention. Lau and Lee (2000) also find that the effect of brand image on purchase intention are significantly related.

\subsection{Trust against Purchase Intention}

Trusts was defined as expectancy held by any individual or any group that the word, promise, verbal or written statement of another individual or group can be relied on (Rotter, 1971). It means that trust is held by the consumer since the brand may proposed a value and creating such a value that the consumer are believing in their mind. In the area of eCommerce, trust has held the important aspect. Gefen and Straub (2004) stated that on the rules inadequacy, consumers try to reduce social uncertainty by relying on trust and familiarities. It means that, when the business were commonly doesn't publicly released their code of conduct, consumers are directly able to recognize the business from its familiarities and brand reputation.

Research finding of Gefen (2000) find that trust is strongly effects purchase intention. Gefen and Straub also find that trust are positively influences consumer intention to buy. Consistent with previous research, Arista (2011) and Prabowo (2014) also find that the trusts was significantly effects purchase intention.

H5: Trust is effects customer purchase intention

H4: Brand image effects trusts

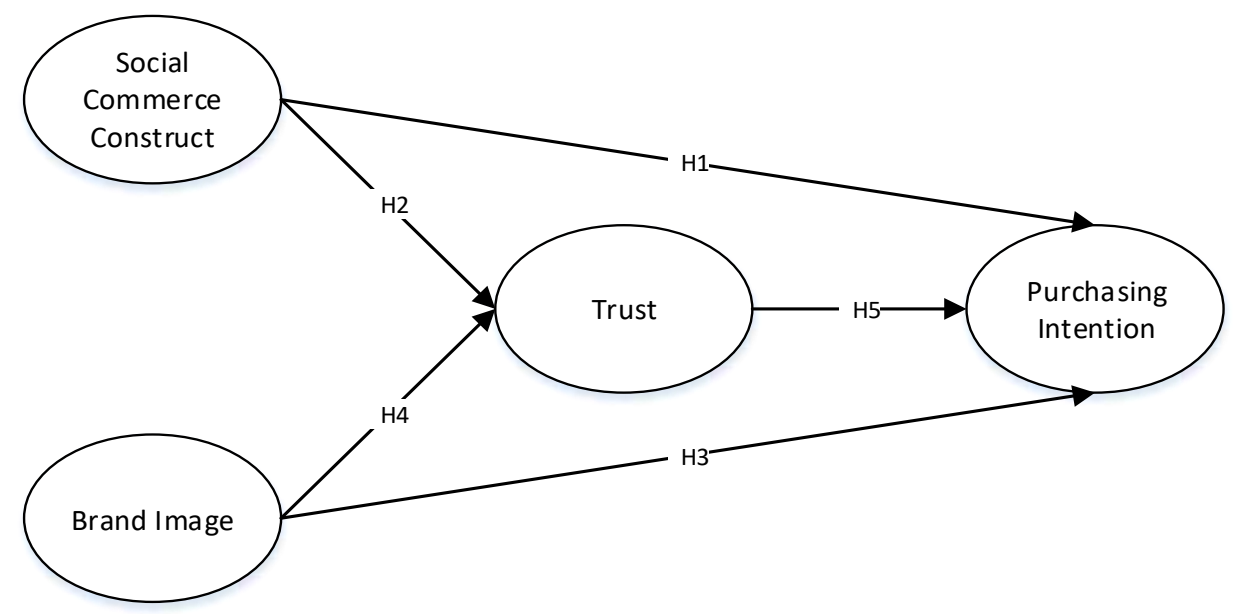

Figure 2Conceptual model 


\section{RESEARCH METHOD}

\subsection{Instrument Development}

The research instrument were developed based on the previous research by an adjustment to fit with the topic being studied. The questions are enclosed in the end of the paper.

\subsection{Data Collection}

The data was collected through survey conducted in Indonesia during two month from August to September 2015. The target was the Instagram follower of @fujifilm_id fan pages that has ever been purchase or tried the product of Fujifilm Indonesia. The pilot test with 20 respondent was used to make sure that the questions and wordings were clearly understood by respondents. The total sample when the research was take a place was as many as 33,050 follower. The survey was done in electronic version by using Google docs namely Google form. The questionnaire was sent by tagging the people that purposively chosen from several criteria. From total 170 tagging, the questionnaire that has been filled is 107 in which only 99 of them can be analyzed due to incomplete answer.The total valid respondent included 80 males and 19 females. The response range was from 15 to 37 years old, which is mostly coming from undergraduate background and senior high grade. The occupation was 80 as a hobby's and 19 from professional photographer.

\subsection{Data Analysis}

The present study applies Generalized Structured Components Analysis (GSCA) which is SEM based as recommended has many advantage over other methods (Gefen, 2011; Hajli, 2015). In addition, SEM is also good for exploratory research (Chin, 1998; Gefen\& Straub, 2004), which is the nature of this research. This method is also suitable for testing a new model and theory as it can be good for confirmatory and exploratory research (Gefen et al., 2011). GSCA is a new model of SEM that based on the component which is it is important in calculation (not in a scale) and also able to be used in the small amount of sample. GSCA is used to confirm the theoretical model through an empirical data rather than deliver any model (Tenenhaus, 2008).

Table 2Variable measurement GeSCA output

\begin{tabular}{lcccccc}
\hline \multicolumn{1}{c}{ Codes } & Factor Loading & SE & CR & FIT & AFIT & NPAR \\
\hline \multicolumn{1}{c}{$\boldsymbol{S C C}$} & & & & 0.701 & 0.695 & 12 \\
x1.1 & $\mathbf{0 . 9 1 8}$ & $\mathbf{0 . 0 1 5}$ & $\mathbf{6 2 . 3 3 *}$ & & & \\
x1.2 & 0.903 & 0.013 & $69.78^{*}$ & & & \\
x1.3 & 0.912 & 0.016 & $58.12^{*}$ & & & \\
x1.4 & 0.906 & 0.013 & $67.4^{*}$ & & & \\
X1.5 & 0.892 & 0.016 & $54.84^{*}$ & & & \\
X1.6 & 0.895 & 0.016 & $56.86^{*}$ & & & \\
& & & & 0.649 & 0.642 & 8 \\
x2.1 & 0.909 & 0.015 & $59.51^{*}$ & & & \\
x2.2 & 0.857 & 0.02 & $42.55^{*}$ & & & \\
x2.3 & 0.906 & 0.013 & $71.36^{*}$ & & & \\
x2.4 & $\mathbf{0 . 9 3}$ & $\mathbf{0 . 0 1}$ & $\mathbf{9 6 . 0 1 *}$ & & &
\end{tabular}




\begin{tabular}{|c|c|c|c|c|c|c|}
\hline$T r$ & & & & 0.674 & 0.667 & 8 \\
\hline Z1.1 & 0.921 & 0.012 & $75.66^{*}$ & \multirow{8}{*}{0.643} & \multirow{8}{*}{0.635} & \multirow{8}{*}{6} \\
\hline Z1.2 & 0.922 & 0.011 & $86.2 *$ & & & \\
\hline Z1.3 & 0.929 & 0.01 & $89.29 *$ & & & \\
\hline Z1.4 & 0.898 & 0.016 & $55.46^{*}$ & & & \\
\hline$P I$ & & & & & & \\
\hline Y1.1 & 0.933 & 0.01 & $94.25^{*}$ & & & \\
\hline Y1.2 & 0.915 & 0.013 & $72.69^{*}$ & & & \\
\hline Y1.3 & 0.928 & 0.013 & $74.01^{*}$ & & & \\
\hline
\end{tabular}

\section{RESULT AND DISCUSSION}

\subsection{Measurement Model}

\subsubsection{Variable measurement}

In measure the results of the study, there will two steps of measurements which is the first was the variable measurement to measure the results of each variable. The results of variable were be shon in table below shows that all of the variable is able to explain the model by the fit criteria and afit criteria that are at least greater than 0.6 which is means that the items in each variable are able to explain the variable for more than $60 \%$ which is the rest is explained by using other items that were not included in this research. The estimated free parameter which meanst that the whole item in each indicator was simply formed by the items stated in this research.

The factor loading indicates on the table above has shown the most seen item in each variable. In SCC variable the most seen items was the item X1.1 estimated as many as 0.918 . The Brand Image Variable is mostly seen from $\mathrm{X} 2.4$ by estimated value 0.93 . The Trust variable is mostly seen from item $\mathrm{Z} 1.2$ estimated as many as 0.22 . The purchase Intention were mostly by the item Y.1.1 estimated as many as 0.933 .

\subsubsection{Overall model}

The estimation results from GeSca are shown in figure 2 table 2. According to the results, all the paths among construct are positive and significant at the 0.05 level. The model validity.

The research is empirically tested social commerce construct and bran image throughout the survey. To do this the research performed bootstrapping in the GeSCA software to test the significance of construct path coefficient identified by critical value. The path coefficient were identified in the figure 2 . The bootstrapping of 99 sample has shown that the social commerce construct has a significant effect against purchase intention at CR 4.21. Therefore, H1 is supported. The effect of social commerce construct on Trust is also shows a positive and significant effect at CR 6.6. Therefore, H2 is supported.

The effect of brand image on trust is also shows a positive and significant effect at CR 3.43. Therefore, H4 is supported. The effect of brand image on purchase intention is also shows a positive and significant effect at CR 2.91. Therefore, H5 is supported.The effect of brand image on trust is also shows a positive and significant effect at CR 2.91. Therefore, H4 is supported.

The effect of trust on purchase is also shows a positive and significant effect at $\mathrm{CR}$ 2.70. Therefore, $\mathrm{H} 4$ is supported. 


\begin{tabular}{cc}
\hline \multicolumn{3}{c}{ Model Fit } \\
\hline FIT & 0.757 \\
AFIT & 0.751 \\
NPAR & 39 \\
\hline
\end{tabular}

Table 4 Structural model Path coefficient

\begin{tabular}{clccc}
\hline No. & \multicolumn{1}{c}{ Direct effect } & Estimate & SE & CR \\
\hline 1. & Social Commerce Construct $(\mathrm{X} 1) \rightarrow$ Purchase Intention & 0.491 & 0.117 & $4.21^{*}$ \\
2. & Social Commerce Construct $(\mathrm{X} 1) \rightarrow$ Trust $(\mathrm{Z} 1)$ & 0.626 & 0.095 & $6.6^{*}$ \\
3. & Brand Image $(\mathrm{X} 2) \rightarrow$ Purchase Intention (Y1) & 0.280 & 0.096 & $2.91^{*}$ \\
4. & Brand Image $(\mathrm{X} 2) \rightarrow$ Trust $(\mathrm{Z} 1)$ & 0.335 & 0.098 & $3.43^{*}$ \\
5. & Trust $(\mathrm{Z} 1) \rightarrow$ Purchase Intention $(\mathrm{Y} 1)$ & 0.250 & 0.092 & $2.70^{*}$ \\
\hline
\end{tabular}

$\mathbf{C R}^{*}=$ significant at, 05 level

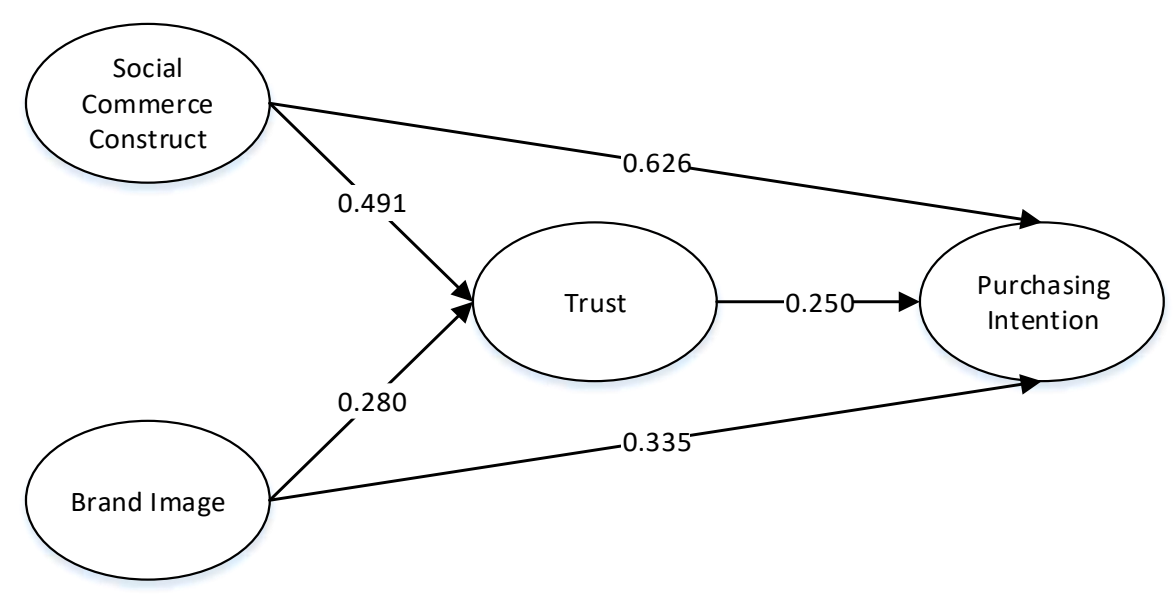

Figure 3 Hypothesis testing results

Table 5Indirect and total effect

\begin{tabular}{lcccc}
\hline \multicolumn{1}{c}{ Effect between Variables } & Direct & Indirect & Total & Results \\
\hline Social Commerce Construct $(\mathrm{X} 1) \rightarrow$ Trust & 0.626 & & & Significant \\
$(\mathrm{Z} 1)$ & $\left(6.6^{*}\right)$ & & & \\
Social Commerce Construct $\rightarrow$ Trust $\rightarrow$ & 0.491 & 0.128 & 0.619 & Significant \\
Purchase Intention & $\left(4.21^{*}\right)$ & $\left(2.10^{*}\right)$ & $\left(6.31^{*}\right)$ & \\
Trust $(\mathrm{Z} 1) \rightarrow$ Purchase Intention (Y1) & 0.250 & & & Significant \\
& $\left(2.70^{*}\right)$ & & & \\
Brand Image (X2) $\rightarrow$ Trust (Z1) & 0.335 & & & Significant \\
& $\left(3.43^{*}\right)$ & & & \\
Brand Image $\rightarrow$ Trust $\rightarrow$ Purchase Intention & 0.280 & 0.084 & 0.364 & Significant \\
& $\left(2.91^{*}\right)$ & $\left(2.12^{*}\right)$ & $\left(4.68^{*}\right)$ & \\
\hline
\end{tabular}

$\mathbf{C} \mathbf{R}^{*}=$ significant at, 05 level 


\subsection{Indirect effect and total effect}

The indirect effect and total of both social commerce construct and brand image against purchase intention mediated by the table 4.

The indirect effect were indicates that the social commerce construct has shown the larger effect estimated as many as 0.128 at CR 2.101 while the brand image shows as many as 0.084 at CR 2.12. The total effect also indicates that the social commerce has a greater effect against purchase intention rather than the brand image.

\subsection{Theoretical and practical contribution}

This research was aimed to understand and then describe the effects of Social Commerce Construct and Brand Image against the Trust and Purchase Intention. The finding concluded in this research is expected to give a theoretical contribution in marketing disciplines, particularly the one that related on marketing information system focusing on social commerce interaction through a social media.

This research is expected to give any insight to the company as practical contribution to define marketing strategies particularly to face the social media interaction with the customer which is the customer need a different treatment. The revolution of social life in digital era is a challenge for the company to get in touch with the customer.

5.4. Research limitation and future research

This research is only focusing on one industry which it may be able to be generalized in the total amount of camera and imaging sectors, but it may still has a possibility that the finding could not applied on cross-company or cross-industry sector. The sample involved in this research is relatively in a small amount, so it may limit the generalization of research finding. Since the research is has a timeline during the design to keep the interpretation are stand still with the current situation, the data amount has to be tolerated in a small amount since the online survey is rather difficult to be held than the direct survey (offline), it is suggested to use a larger sample and greater instrument to get a deeper insight in the study on cross company or even cross industry if possible by several adjustment.

\section{CONCLUDING REMARK}

This research is studying about the effect of social commerce construct and brand image against trust and consumer purchase intention. The framework was coming from the study in the area of information system namely social commerce construct. This variable then compared with the brand image. The results has shown that both direct and indirect mediated by trust, social commerce construct has a greater impact against the purchase intention. The total effect also shows that social commerce construct has a greater effect against the purchase intention.

The main contribution of this research is that when empirically tested, social commerce constructs showed that social relationships and interactions of individuals in these platforms, which have emerged in instagram, influence consumer behavior. It is also important to note that when the brand image has a lesser effects against consumer purchase intention, the company need to enforce its brand against consumer brand knowledge to educate the consumer about the brand.

The suggestion for the company, this research can be used as a reference to evaluate the current strategy related to social media strategies. For the consumer, it would be great if we know an information about particular product so it can be suitable with our necessity. For future researcher, the larger amount of sample and also on cross company or cross industry, will give a greater and deeper insight related to social commerce construct to enriching the literature. 


\section{REFERENCES}

Aghekyan, Marine. 2009. The role of product brand image and online store image onPerceived risks and online purchase intentions. Alabama: Auburn Universities

Aghekyan, Fosrthye, \& Kwon. 2012. The role of product brand image and online store image on perceived risksand online purchase intentions for apparel. Journal of Retailing and Consumer Services 19 (2012) 325-331

Arista, Elisabeth 2011. Analisispengaruhiklan, brand trust dan brandimage

terhadapminatbelikonsumentelkom speedy di kotasemarang. Diponegoro University

Bagozzi, R. P., \&Dholakia, U. M. 2002. Intentional social action in virtual communities. Journal of Interactive Marketing, 16(2), 2-21 (John Wiley \& Sons).

Chen, J., Xu, H., \&Whinston, A. B. 2011. Moderated online communities and qualityof user-generated content. Journal of Management Information Systems, 28(2),237-268.

Chin, W. W. 1998. Issues and opinion on structural equation modeling (Editorial). MIS Quarterly, 1. Available from http://search.ebscohost.com/login.aspx?dire $\mathrm{ct}=$ true $\& \mathrm{db}=$ buh $\& \mathrm{AN}=345479 \&$ site $=$ ehost live

Do-Hyung, P., Jumin, L., \&Ingoo, H. 2007. The effect of on-line consumer reviews on consumer purchasing intention: The moderating role ofinvolvement. International Journal of Electronic Commerce, 11(4), 125148.http://dx.doi.org/10.2753/jec10864415110405

Emarketer. 2014. APAC Ranks No. 2 Worldwide for Social Network Ad Spend Share. Emarketer.com, retrieved 16/3/2015 from
[http://www.emarketer.com/Article/APACRanks-No-2-Worldwide-Social-NetworkAd-Spend-Share/1011221]

Emarketer. 2014. Digital Grabs a Sliver of Ad Spend in India, Indonesia. Emarketer.com retrieved on 16/3/2015 from [http://www.emarketer.com/Article/DigitalGrabs-Sliver-of-Ad-Spend-IndiaIndonesia/1011747\#sthash.kRjZRxmq.dpuf ]

Ferrinadewi, Erna. 2008, "MerekdanPsikologiKonsumenImplikasipa daStrategiPemasaran", edisipertama, Grahallmu, Yogyakarta.

Gefen, D., Rigdon, E. E., \& Straub, D. 2011. An update and extension to SEM guidelines for administrative and social science research. MIS Quarterly, 35(2), iii-A7

Gefen, D., \& Straub, D. W. (2004). Consumer trust in $\mathrm{B} 2 \mathrm{C}$ e-commerce and the importance of social presence: Experiments in e-products and e-services. Omega,32(6), 407-424.

http://dx.doi.org/10.1016/j.omega.2004.01. 006

Hajli, N. (2014). The role of social support on relationship quality and social commerce. Technological Forecasting and Social Change, 87, 17-27.

Hajli, N., \& Lin, X. 2014. Exploring the security of information sharing on socialnetworking sites: The role of perceived control of information. Journal of BusinessEthics, $1-13$. http://dx.doi.org/10.1007/s10551-0142346-x

Hajli. 2015. Social commerce constructs and consumer's intention to buy. International Journal of Information Management 35: 183-191

Hargadon, A. B., \&Bechky, B. A. 2006. When collections of creative become creative collectives: A field study of problem solving 
at work. Organization Science, 17(4), 484500 .

Hubanic, Arijana\&Hubanic, Vedrana. 2008.Brand Identity and Brand Image. University of Gothenburg fromhttps://gupea.ub.gu.se/bitstream/2077/ 19462/1/gupea_2077_19462_1.pdf accessed on $08 / 13 / 2015$

Keller, K. L. (1993). Conceptualizing, measuring, and managing customer-based brandequity. Journal of Marketing, 57(1), 122.

Kim, Sanghyun\& Park, Hyunsun. 2013. Effects of various characteristics of social commerce (sCommerce) on consumers' trust and trust performance. International Journal of Information Management 33: $318-332$

Kotler et al., 1999. Principles of marketing. New York: Prentice Hall

Kotler, Philip dan Keller, Kevin Lane. 2005. ManajemenPemasaran, Indeks, Jakarta.

Lau, G.T., and Lee, S.H. 2000. Consumer Trust in Brand and the Link to Brand Loyalty. Journal of Market Focused Management. 4, pp. $341-370$

Liang, T.-P., \& Turban, E. 2011. Introduction to the special issue social commerce:A research framework for social commerce. International Journal of ElectronicCommerce, 16(2), 5-14.

Ming-Hsien, Y., Chandlrees, N., Binshan, L., \& Hung-Yi, C. 2009. The effect ofperceived ethical performance of shopping websites on consumer trust. Journalof Computer Information Systems, 50(1), 15-24.

Mutz, D. C. 2005. Social trust and e-commerce: Experimental evidence for the effects of social trust on individuals' economic behavior. Public Opinion Quarterly, 69(3), 393-416. http://dx.doi.org/10.1093/poq/nfi029
Prabowo, Riefky. 2014. Analisispengaruhiklan, brand trust dan brand imageterhadapminatbelikonsumenmastinek strakkulitmanggis di kota Malang. University of Brawijayamalang

Ridings, C. M., \&Gefen, D. 2004. Virtual community attraction: Why people hangout online. Journal of Computer-Mediated Communication, 10(1)

Rothberg, D. 2005. "Yahoo Unleashes a UserPlugged Shoposphere," in: eWeek.com

Rotter JB. 1971. Generalized expectancies for interpersonal trust. American Psychologist 26:443-50.

Rubel, S. 2005. "2006 Trends to Watch Part Ii: Social Commerce," in: Micro Persuasion.

Semuel, Hatane\&Lianto, Adi S. 2014. Analisis ewom, brand image, brand trust danminatbeliproduk smartphone di Surabaya. Jurnalmanajemenpemasaran, vol. 8, no. 2, October 2014

Stephen, A.T., and Toubia, O. 2010. "Deriving Value from Social Commerce Networks," Journal of Marketing Research (47:2), April, 2010, pp. 215-228.

M. Tenenhaus, Component-based Structural Equation Modelling, [Online], http://www.hec.fr/heccontent/download/47 97/115324/version/2/file/CR887TENENH AUS.pdf, 2008.

Wijaya, Bambang. 2013. Dimensions of Brand Image: A Conceptual Reviewfrom the Perspective of Brand Communication. European Journal of Business and Management, Vol.5, No.31, 2013

Yubo, C., \&Jinhong, X. 2005). Third-party product review and firm marketing strategy. Marketing Science, 24(2), 218-240. http://dx.doi.org/10.1287/mksc.1040.0089

Zang, Michael. 2015. Graph: How the Mirrorless Camera Industry in Japan Changed in 2014. Petapixel.com retrieved 
[http://petapixel.com/2015/01/31/graph-

mirrorless-camera-industry-japan-changed2014/]

\section{Social Commerce Construct}

Hajli (2014); Kim and Park (2012)

X1.1 My friend recommendation are reliable

X1.2 My friend recommendation are frank

X1.3 Product reviews are trustworthy

X1.4 My friend reviews are reliable

X1.5 I feel my friends in this community are generally reliable

X1.6 I feel my friends in this community are trustworthy

\section{Brand Image}

Mariné Aghekyan (2009); Arista (2011);

Prabowo (2014)

X2.1 This brand continuously improves its features

X2.2 This brand has excellent quality

$\mathrm{X} 2.3$ This brand is in fashion

$\mathrm{X} 2.4$ This brand is keeping with my lifestyle.

Trust

Hong and Cha (2013); Hajli (2014); Hong and Cha (2013); Gefen and Straub (2004);

Chaudhuri and Holbrook (2001)

Z1.1 I believe that the Fujifilm_id online store attached in the product post is trustworthy

Z1.2 Promises made by Fujifilm_id on its products description are reliable

Z1.3 Fujifilm_id knows how to provide excellent promotion and services on its products

Z1.4 Fujifilm_id products are reliable

\section{Purchase Intention}

Hajli (2014); Hong \& Cha (2013); Prabowo (2014); Arista (2011)

Y1.1 I would like to buy product based on this fan page

Y1.2 I would like to try the product of Fujifilm_id

Y1.3 I would like to know more about the product of Fujifilm_id 